\title{
Intertextuality in Online News Opinion Article on Industrial Revolution 4.0: Its Type and Discursive Practice
}

\author{
Aan Ramadhansyah Rahayu, Rosaria Mita Amalia \\ Faculty of Cultural Science, Department of Linguistics, Universitas Padjadjaran \\ Bandung, Indonesia \\ E-mail: arrahayu13@gmail.com, rosaria.mita.amalia@unpad.ac.id
}

\begin{abstract}
This study deals with intertextuality in opinion article on industrial revolution. This study is a part of discourse analysis which aims to discover types of intertextuality in the article and to reveal its social practice (discursive practice). The study follows Fairclough (2003) view of language in use: as an element of social life which is closely interconnected with other elements, therefore this study applied descriptive qualitative method. The results show Implicit Quotation and Indirect Quotation are dominantly used in the articles. Implicit Quotation used as strategy to throw arguments, and Indirect Quotation is used to bring authoritative voice from outside into the articles. The discursive practice of intertextuality in the articles is showing an informal discussion, but still having an academic sense in newspaper article to make it sounds such an authoritative discussion. Therefore, people who read the article would acknowledge the writers' idea and believe their argument and opinion.
\end{abstract}

Keywords: intertextuality, discursive practice, discourse, online newspaper, opinion article

\section{INTRODUCTION}

Online newspaper provides a space to discuss about the current issues that happened in the country, this space in online newspaper is called 'opinion' or 'kolompembaca'. The space is used to covered some issues that has been talked over and over in the society. Definitely, this space become a medium for the online newspapers' readers to established their idea, their argument and opinion toward the issues, and one of the hot issue which has been delivered greatly in Indonesia is regarding on the industrial revolution issue. The readers sent their opinion, argument and idea in the form of article which is sent to newspaper. In this way, the article is potentially influence the public opinion regarding on the issue, either to support or to challenge the current practice (Fairclough, 2003)

However, the article which has been sent to online newspaper 'opinion' or 'reader column' contains various linguistic aspects that can be investigated. One of the 
linguistic aspects that is investigated here is the term intertextuality. In fact, intertextuality always exists in any kind of writing (Chandler, 2002). Therefore, it might be interesting to investigate the intertextuality in the opinion articles on Industrial Revolution. The investigation is focused on analyzing its types and its discursive practice. Hopefully, the findings of this study could give knowledge to others about what should be considered when writing an article opinion in order to influence others.

The term intertextuality itself, firstly coined by Julia Kristeva in which she developed Bakhtin's works in Russian which had not widely accessed until Kristeva talked about it in in her doctoral thesis in 1966 (Graham, 2000). The most basic idea of intertextuality is that texts do not appear in isolation, but unhesitatingly in relation to other texts (Fairclough, 2003) (Fairclough, 2003), or in other words it is a study that discussed how literary work is related to previous literary works. Nevertheless, intertextuality is not only limited in literary theory or works, its use has been expanded and applied in other discipline such as discourse analysis, media and social studies (Costello, 2007).

Meanwhile, the term text in this study is specifically defined as alinguistictext which supports a certain social-interaction function. Surely, texts composed of large body of paragraphs reveal explicitely its relation to other texts. The writers of the article use resources to provide by the prior text in their own text. Thus, these texts are not more than an accumulation of the writer's own text and other writers' texts assimilate in his/her text.

The social meaning of intertextuality is interpreted in relation to a certain social practice to which a particular sort of text attachs. The behavior of how it is paradigmatically used across texts in the same genre is the major clue to reveal its social meaning. it is a kind of what Fairclough (1992) said as 'discursive practice' which involves processes of the text production, distribution, and consumption, and the nature of the processes varies among different types of discourse according to social factors.

This study is part of discourse analysis. The definition of the term discourse here follows Fairclough (2003) as : the particular view of language in use..... as an element of social life which is closely interconnected with other elements. A certain discourse is arranged by series of texts which possess basic elements of distribution and 
consumption to share. The term discourse here refers to (i) series of texts which are in the same register and genre and (ii) series of texts which reveal a general and abstract portrait. Generally, it isconsidered to be in length discussion.

Noticing how intertextuality comes into articles, this study covers tworesearch questions, (1) what are the types of intertextuality which dominantly appear in the opinion articles? (2)What is the discursive practice of the articles?

\section{METHODOLOGY}

This study is a discourse analysis follows the model of discourse analysis which has been introduced by Fairclough $(1992,2003)$. It concerns with the analysis of texts to find out the features of intertextuality. After finding the features of intertextuality, continue to find out the types on intertextuality dominantly appear in the articles. Next, present those types of intertextuality into a table so that it is readable to figure or to analize the discursive practice.The types of intertextuality was analized to figure out what sort of social practice is reflected and form the nature of its behavior.

This study investigates online newspaper articles, the topic which has something to do with industrial revolution issue. The data are six articles in the space 'opinion'. The data of this study are presented in Table 1

Table 1 Data of the Study

\begin{tabular}{|l|c|c|c|}
\hline No. & Online News & Region & Column's name \\
\hline 1. & Harian Jogja(HJ1) & Regional & Opini \\
\hline 2. & Harian Jogja(HJ2) & Regional & Opini \\
\hline 3. & Detik News(DN) & National & Opini \\
\hline 4. & Sindo News(SN) & National & Opini \\
\hline 5. & Kabar Indonesia(KI) & National & Opini \\
\hline 6. & Jateng Tribuns(JT) & Regional & Opini \\
\hline
\end{tabular}


Someonline news published articles on 'RevolusiIndustri'. The data were collected from the online news articles range $2018-2019$.

\section{RESULTS AND DISCUSSION}

\section{General Result of Intertextuality Analysis in Numbers}

There are 312 sentences from 6 articles that have been analyzed. Out of those sentences there are 79 sentences considered to be intertextuality. The data analysis also reveals that intertextuality exists in every 'opinion' article. The result of analysis can be summarized in Table 2.

Table 2 The Result of Intertextuality Analysis in Numbers

\begin{tabular}{|l|l|c|c|c|c|c|}
\hline No. & $\begin{array}{c}\text { Online } \\
\text { News }\end{array}$ & $\begin{array}{c}\text { Number } \\
\text { of } \\
\text { sentences }\end{array}$ & $\begin{array}{c}\text { Number of } \\
\text { intertextuality }\end{array}$ & $\begin{array}{c}\text { Number of non } \\
\text { intertextuality }\end{array}$ & $\begin{array}{c}\text { Intertextuality } \\
(\%)\end{array}$ & $\begin{array}{c}\text { Non- } \\
\text { intertextuality } \\
(\%)\end{array}$ \\
\hline 1. & HJ1 & 33 & 9 & 24 & 27 & 83 \\
\hline 2. & HJ2 & 47 & 6 & 41 & 13 & 27 \\
\hline 3. & DN & 61 & 15 & 46 & 25 & 40 \\
\hline 4. & SN & 52 & 13 & 39 & 25 & 48 \\
\hline 5. & KI & 63 & 23 & 40 & 37 & 58 \\
\hline 6. & JT & 56 & 13 & 43 & 23 & 41 \\
\hline \multicolumn{2}{|r|}{ Total } & 312 & 79 & 233 & 149 & 298 \\
\hline
\end{tabular}

\section{TYPES OF INTERTEXTUALITY}

The data analysis results in the type of intertextuality that realized in three types, (i) Citation, (ii) Quotation, and (iii) Allusion. Citation is a type of intertextuality whose source is located in brackets as in (1).

(1) Berdasarkan Bank Dunia (World Bank, 2018), Indeks Sumber Daya Manusia (Human Capital Index/HCI) Indonesia sebesar 0,53 atau peringkat ke-87 dari 157 negara.(KI Data 5)

According to World Bank (World Bank, 2018), Indonesian Human Capital Index/HCL is 0,53 or in the rank 87 out of 157 countries. 
Quotation refers to a type of intertextuality which may fall into (i) direct quotation or (ii) indirect quotation. Direct quotation and Indirect quotation are identified based on orthographic marker "quotation marks" and source's voice which links the source with his/her text. Both can be seen in (2).

\section{(2.a) Direct Quotation}

Hal ini sejalan dengan pandangan Venti Eka Satya (2018) yang berkata,"dunia saat ini telah memasuki era revolusi industry keempat.Pada revolusi industry ini terjadi lompatan besar dalam sector industri, ketika teknologi informasi dan komunikasi dimanfaatkan sepenuhnya. Agar mampu bersaing, Indonesia harus mampu mengadopsi Industri 4.0 ini dan mempersiapkan strategi yang tepat di semua sektor.” (HJ2 Data 2)

This is in line with the view of VentiEkaSatya (2018) who said, "the world has now entered the era of the fourth industrial revolution. In this industrial revolution there was a big leap in the industrial sector, when information and communication technology was fully utilized. In order to be able to compete, Indonesia must be ableto adopt this Industry 4.0 and prepare appropriate strategies in all sectors.

\section{(2.b) Indirect Quotation}

Belum lama ini, Presiden Joko Widodo juga mengungkapkan bahwa pemerintah telah mengelompokkan lima industry utama yang disiapkan untuk Revolusi Industri 4.0. (HJ1 Data1)

Recently, PresidenJokowi stated that the government has categorized five main industries to face Industrial Revolution 4.0.

Allusion is a type of intertextuality whose presence in the articles is implicit. It can be realized as Implicit Quotation, Negation, or Framing. Implicit Quotation is a type of Allusion where the source of its text is not presence. Negation is a type of Allusion which is identified on the basis of the presence of intertextual negation. Next, Framing is a type of Allusion which is related to the change of semantic domain. The examples are presented in (3). 


\section{(3.a) Implicit Quotation}

Ada pendapat bahwa profesi dokter akan mengalami persaingan. (SN Data 4).

There is an an opinion that the medical profession will experience competition.

\section{(3.b) Negation}

Tak cukup hanya dengan penguasaan teknologi, tetapi harus dilengkapi penguasaan sejumlah bahasa asing agar bias komunikatif pada tingkat global. (DN Data 3)

Having ability in technology is not enough, but must be equipped with the ability of speaking foreign languages so that they can be communicative at the global level.

\section{(3.c) Framing}

Pemuda tentunya menjadi tulang punggung dalam mewujudkan Indonesia maju. (JT Data 6)

Youth certainly becomes the backbone in realizing advanced Indonesia.

(3.a) is called as a Quotation because it contains one of the features of Quotation, i.e. the presence of the intertextual voice "pendapat" (opinion). In fact, the source to which the text being intertextualized referred is not present. Therefore, it is not considered as Quotation though partly it resembles a quotation. The source from where the text was quoted has to be noted if it is a quotation. That is why it is called Implicit Quotation.

The text being intertextualized in point (3.b) is also not constituted explicitly. It means there is intertextuality which can be explained by the use of negation which functions to reject a linguistic text which has been produced. The negation in (3.b) indicated that knowing technology is not enough, but needs to be able to speak other global languages. Here the presence of intertextuality is identified on the basis of the use of intertextual negation, i.e. negation which has function to intertextualize other texts into a text. Framing in (3.c) exemplified by the phrase 'tulang punggung' which refers as 'main actor'. 


\section{The Use of Types of Intertextuality}

The data in Table 3 below shown that Implicit Quotation is the dominant type of intertextuality in the articles.

Table 3 The Types of Intertextuality

\begin{tabular}{|c|l|c|c|c|c|c|c|}
\hline \multirow{2}{*}{ No } & \multirow{2}{*}{ Newspaper } & \multirow{2}{*}{ Citation } & \multicolumn{2}{|c|}{ Quotation } & \multicolumn{3}{|c|}{ Allusion } \\
\cline { 4 - 8 } & & & Direct & indirect & Implicit & Negation & Framing \\
\hline 1. & HJ1 & - & - & 5 & 4 & - & 3 \\
\hline 2. & HJ2 & - & 1 & - & 4 & 1 & - \\
\hline 3. & DN & - & 2 & 5 & 7 & 1 & 1 \\
\hline 4. & SN & - & 1 & 3 & 8 & 1 & - \\
\hline 5. & KI & 16 & 4 & - & 3 & - & - \\
\hline 6. & JT & - & - & 7 & 5 & 1 & 2 \\
\hline & Total & 16 & 8 & 20 & 31 & 4 & 6 \\
\hline
\end{tabular}

The Implicit Quotation used as a method of providing arguments in the articles, the writers do not present the source therefore the arguments seemed as if naturally the writers' idea, in fact they have been intertextualized with other texts which have been read before by the writers. Next, Indirect Quotation is also used dominantly in the article, however Indirect Quotation as presented in (2b) is different from the way it is used in academic text. It is pure Indirect Quotation which differs from an academic text which partly citation. In academic text it is not only authoratitave voice which necessary but also the traceability of its source. Therefore, Indirect Quotation in the articles only mentioned the authority side of quotation as an academic features since it does not show the traceability side of quotation as an academic features which certainly has to be put in the citation form.

This discursive practice connects the necessity of being informal in providing arguments, hence showing academic feature in the articles. Making data presentation and explanation seem authoritative obviously require academic sense instead only giving implicit argument. This is applied by bringing authoritative voice from outside into the articles. An academic text uses citation to realize it. However, the articles is not 
an academic setting. The sense of academic in the articles is reduced by giving implicit quotation and applying indirect quotation.

\section{CONCLUSION}

This study shows briefly three types of intertextualitywhich possibly emerge in Indonesian texts. Those are citation, quotation (direct and indirect quotation), and allusion (implicit quotation, negation, framing). Out of five sub-type of intertextuality, Implicit Quotation and Indirect Quotation are dominantly used in the articles. The discursive practice of intertextuality in the articles is showing an informal discussion, but still having an academic sense in news article to make it sounds such an authoritative discussion. Therefore, people who read the article would acknowledge the writers' idea and believe their argument and opinion.

\section{REFERENCES}

Agger, G. (1999). Intertextuality Revisted: Dialog and Negotiations in Media Sttudies. Canadian Aesthetic Journal, Volume 4.

Chandler, D. (2002). Semiotics: The Basics. London: Routledge.

D, A. (1994). Intertextuality Revisited: Dialog and Negotiations in Media Studies. Canadian Aesthetic Journal, Volume 4.

Fairclough, N. (2003). Analyzing Discourse: textual Analysis for Social Research. London: Longman.

Fairclough, N. (1995). Critical Discourse Analysis, the Critical Study of Language. London: Longman.

Fairclough, N. (1992). Discourse and Social Change. Cambridge: Polity Press.

Graham, A. (2000). Intertextuality (The New Critical Idiom). London: Routlege.

Pulungan, Subroto, Tarjana, Sumarlam. (2010). Intertextuality in Indoensian Newspaper Opinion Articles on Education: Its Types, Function, and Discursive Practice. TEFLIN Journal, Volume 21. 